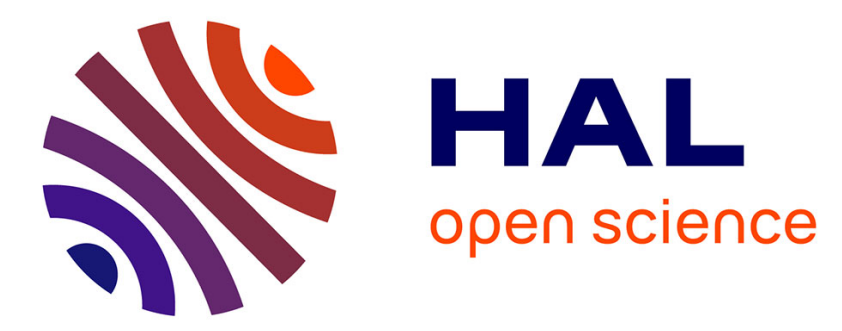

\title{
Innovating Performing Arts Management Through a Product Lifecycle Management Approach
}

\author{
Lazoi Mariangela, Marra Manuela, Quarta Lorenzo, Corallo Angelo
}

\section{To cite this version:}

Lazoi Mariangela, Marra Manuela, Quarta Lorenzo, Corallo Angelo. Innovating Performing Arts Management Through a Product Lifecycle Management Approach. 15th IFIP International Conference on Product Lifecycle Management (PLM), Jul 2018, Turin, Italy. pp.420-431, 10.1007/978-3-030-016142_39. hal-02075639

\section{HAL Id: hal-02075639 \\ https://hal.inria.fr/hal-02075639}

Submitted on 21 Mar 2019

HAL is a multi-disciplinary open access archive for the deposit and dissemination of scientific research documents, whether they are published or not. The documents may come from teaching and research institutions in France or abroad, or from public or private research centers.
L'archive ouverte pluridisciplinaire HAL, est destinée au dépôt et à la diffusion de documents scientifiques de niveau recherche, publiés ou non, émanant des établissements d'enseignement et de recherche français ou étrangers, des laboratoires publics ou privés. 


\title{
Innovating Performing Arts management through a Product Lifecycle Management approach
}

\begin{abstract}
Cultural and Creative industry is a wide sector with different specializations and application areas. It refers to the creation and distribution of services or products of a cultural or artistic nature such as gaming, visual arts, movie, performing arts, music and theatre.

IT systems supporting this sector are not widely used and there is a lack of tools supporting the activities management and data and information retrieval, sharing and systematization. With a focus on Performing Arts, existing tools do not help to manage completely three critical areas: Tour Management, Stage Configuration Management and Social Network Analysis.

With particular attention to configuration management, that refers to how change the structure of artists and instrumentations on the stage in different performances, the study aims to analyze the context of Cultural and Creative Industries, studying the concept of Product (Live Event), its lifecycle and relative critical areas. A new integrated Data Model is proposed to help managers in cultural and creative events organization and management and extending the view of complex products on this industry result prospective. Data model entities and attributes will be discussed for evaluating an extension of current PLM systems also in this field.
\end{abstract}

Keywords: PLM, product lifecycle, performing arts, cultural and creative industries

\section{Introduction}

Cultural and Creative Industries (CCIs) are industries whose principal purpose is production or reproduction, promotion, distribution or commercialization of goods, services and activities of a cultural, artistic or heritage-related nature" [1]. In recent years, CCIs have been characterized by great income (US $\$ 2,250$ billion of global revenues in 2013) [1] and are the target of many public and private initiatives (regional and European) to drive economic growth and create jobs.

Despite their importance and potential value, there are few definitions about what Industries are part of the Cultural and Creative domain. One of these has been provided by UNESCO and includes the following eleven sectors: Advertising, Architecture, Books, Gaming, Music, Movie, Newspaper and Magazines, Performing Arts, Radio, TV and Visual Arts. [1]

The sales of physical products, for years the main source of income for artists and CCIs organizations, have dramatically decreased due to a different way to consume a product by customers. On the other hand, digital sales are growing steadily, but they do not compensate the loss resulting from the decrease in physical sales.

In this scenario, events can represent a great source of income and a perfect means of advertising a cultural and creative product. 
Starting from this observation, the need to organize increasingly attractive and efficient events emerges in order to attract as more paying spectators as possible and media attention.

The cultural and creative products like festivals, concerts, events, tours, exhibitions, theater performances, etc. have their own life cycle that could be managed in a more efficient way by borrowing technologies and approaches used in the management of complex products (Product Lifecycle Management, Business Process Management, Social Network Analysis, Virtual Reality and simulation, etc.). The concept of new product risk is more complex in an arts context. Firstly, many of the risk factors that apply to commercial products apply also to performing arts products - perhaps even more so. Colbert [2] argues that three factors make performing arts products particularly risky the impossibility of testing the new product, planned limited life cycle of the product and inability to stock the product - and that these elements "prove that cultural enterprises are high-risk ventures that have no equivalent in other sectors of the economy". It could be argued, however, that these are in fact similar to the challenges faced by those involved in developing new services.

Furthermore, in the organization of a Cultural and Creative Event, it is important to consider the definition of Project that citing the PMI (Project Management Institute) is "a temporary endeavour undertaken to create a unique product or service" [3]. It is possible to say that a Cultural and Creative Event is no more than a Project with a specific Scope: the cultural and creative one. Both have a Life Cycle and the running of performance is just the latest of several steps that usually involve a lot of people and stakeholders with heterogeneous skills and different roles and several risks to consider and deal with.

Based on these premises and on the preliminary studies carried out for the start of the MYA (Manage Your Arts) research project, which involves University and companies operating in the performing arts industry, the paper aims to propose phases and areas of the entire Lifecycle of an event and suggests a new and integrated Data Model. This one will be the basis for defining a set of technological solutions enabling the improvement of cultural and creative events organizational processes.

In the next sections of the paper, the studies related to the topic of interest, the research methods used and the reached results are described. A section of conclusions ends the paper.

\section{Background}

PLM stands for Product Lifecycle Management and its value is increasing particularly in the manufacturing and high-tech sectors [4]. Today, PLM is recognized as a necessity for organizations that want to become more innovative and meet the challenges of the competitive environment. Being an innovative business not only means creating innovative products, but also improving the processes by which those products are manufactured and supported throughout their life cycle [5]. At the highest level, the objective of PLM is to increase product revenues, reduce product-related costs, maximize the 
value of the product portfolio, and maximize the value of current and future products for both customers and shareholders [6].

PLM can be defined as a strategic business approach that supports all phases of a product's life cycle, from concept to disposal, providing a unique and timed source of product information. By integrating people with processes and technologies and ensuring consistency of information, traceability and long-term archiving, PLM enables organizations to collaborate within the extended enterprise ( [7], [8]). The objective of the PLM is to track and manage all activities, data and information flows during the product development process and then during maintenance and support phase [9]

PLM methodologies and tools have continued to grow in traditional sectors such as automotive [10], aerospace and defence industries ( [11], [12] ). They have recently begun to emerge in non-traditional markets such as life sciences, energy [13] , architecture [14] and shipbuilding.

Further studies analyze the application of PLM in non-conventional sectors such as fashion [15], luxury [16] and food industry ( [17], [18]). In this field starting from the analysis of the specific new product development (NPD), authors try to deepen the application of PLM in the industry, evaluating also technology suppliers' offer.

D'Avolio et al. study [15] describes the main characteristics of PLM implementation in the fashion industry. Starting from an overview of fashion NPD, they studied in depth PLM adoption through a descriptive exploratory research, based on interviews and information, available on websites and industry-specific magazines thanks the growth of PLM projects within the fashion industry and the increasing number of industry-specific tools. They presented how through PLM, fashion companies are able to manage standardized processes, based on timely and correct decisions. PLM technologies support several core tasks, such as material and colour management, merchandise planning, product sourcing and visual merchandising, but also manufacturing and retailing. The advantages of its adoption are shorter product development process, a greater control of information, a reduction in inventory, non-value-added tasks and time to market.

Vezzetti et al. [16] analysed PLM in luxury fashion scenario adopting a user centred approach. They formalized the key luxury NPD processes, in terms actors involved, information/data received and produced, tools/methodologies involved for each process, and possible constraints. This task was preparatory to the collection of the real functional requirements of a Collaborative Product Development and Management solution identifiable with a PLM solution.

Pinna et al. ( [17], [18]) analysed the level of knowledge of PLM systems in the food sector from the literature and the markets points of view, observing how it is still low even if many vendors of PLM solutions offer dedicated and customized solutions for the food industry. The researchers aimed to understand how the use of PLM systems could enhance the performances related to the different phases of the NPD in food industry studying in depth the related processes. They complete the analysis interviewing some of the main Italian and foreign food companies about actors participating to the process, the kind of performances considered important for the food NPD, the forces (internal and external) that lead to the decision to develop a new product and how long lasts the process (from concept to the launch stages). Their final goal was to understand how the PLM functionalities can affect the performance of the various activities of the 
NPD process taking into account four strategical interest of the PLM solution deployment: the sharing of information, the optimization of its processes, the deploying a structured NPD methodology, and the analysis and the anticipation of the risks linked to the product/process data.

Although studies carried out in different sectors cannot make direct contributions to the identification of life-cycle stages due to the specificity of the cultural product, many insights and suggestions can be made by comparing the methods and approaches adopted in these sectors.

There are still no cases of applications of PLM approaches in the context of CCIs. It is a world that has recently become made up of professionals and the need to innovate, improve and standardize processes is beginning to emerge.

Some authors examined the application of NPD models to performing arts ( [19], [20]) or in general, to the arts industry, that is nourished and sustained by innovation and creativity. They assumed a marketing perspective, focusing more on initial phase of concept definition. The nature of artistic products appears ill-suited to traditional NPD model witch assume the new development from idea generation to launch as a response to consumer need. Crealey [19] pointed out that arts organizations do not formally consider the management of a product's lifecycle, although it is a critical stage in the NPD process. The life cycle of a performing arts product can encompass the initial season, repeat performances in later years, re-staging, school performances and tours. Life-cycle management can lead to sustainability in the arts, since repositioning one product offering for different audience segments will save money and time.

Others instead have compared managerial works in performing arts, although dealing with the fine arts and concerned with creativity, audience appreciation and good art, to similar task of managers in industry and project management activities [21]. Lindgren and Packendorff [22] analyzed theatres as project-based organisations, considering project management as a part of a general trend towards the 'managerialisation' of the performing arts.

Finally, Holmes and Ali-Knight [23] discussed about the importance of lifecycle of events mainly in the tourism field where also others scholars have done different research (e.g. [24]). They suggests extending the TALC (Tourism Area Life Cycle) model to the events and festivals context, considering events and festivals as products. Although the model created in tourism literature links the development cycle of tourism destinations to that of products in the product life cycle model, they did not explicitly mention PLM but just suggested seven event trajectories offering event managers the means for managing their events' future plans.

\section{$3 \quad$ Research Design}

The paper aims to address the research questions: What are the lifecycle phases of an event and the main process areas impacted by a lifecycle approach? How can be events elements systematized in a Data Model useful to guide technological developments?. These research questions are emerged during a workshop in which engineers 
and technicians involving on research activities in the manufacturing field discussed PLM impacts and extension.

To answer the research questions firstly, six semi-structured interviews were carried outwith different profiles involved in the management of performing arts: musician, band, event organizer, sound manager, theatres manager and cultural association.

The collected evidences were organized in a framework and proposed for implementation in a research project based on a public call in Apulia Region in the South of Italy. The project is named MYA (Manage Your Arts) and has as partners University of Salento, Bass Culture, Cantieri Teatrali Koreja, Officine Cantelmo and Cool Club. The industrial partners cover the field of music booking agency, and production and organization of concerts, ballets, theatrical performances, conventions and congress. Apulia Region is the only Region in Italy with a productive District related to Creative and Cultural Industry and to recognize a significant role of new technologies and methods for this industry among the regional strategic areas of innovation. Therefore, it is the right context to implement the proposed idea.

To enforce the preliminary view originated by the interviews, and as preliminary phase for the starting of the project, five focus groups were launched to create a common background, defines best practices and to identify area, elements and phases of cultural events lifecycle. Four focus groups were specific to share information about the activities of each companies and a last one, was realized to discuss the observed practice and define common elements.

In the following figure, the main steps of the research method are summarized.

\begin{tabular}{|c|c|c|}
\hline $\begin{array}{l}\text { Data Collection } \\
\text { Method }\end{array}$ & Interviewees Characteristics & Gathered Information \\
\hline $\begin{array}{l}\text { Semi-structured } \\
\text { interviews } \\
\text { N.6 }\end{array}$ & $\begin{array}{l}\text { Different Profiles involving in } \\
\text { Performing Arts: musician, band, event } \\
\text { organizer, sound manager, theatres } \\
\text { manager and cultural association }\end{array}$ & $\begin{array}{l}\text { - Issues to be managed for events organizations; } \\
\text { - Problems; } \\
\text { - Involved Roles; } \\
\text { - Used Documents; } \\
\text { - Needs. }\end{array}$ \\
\hline \multirow{5}{*}{$\begin{array}{c}\text { Focus Group } \\
\text { N.5 }\end{array}$} & Booking Activity Managers & \multirow{4}{*}{$\begin{array}{l}\text { - Activities; } \\
\text { - Phases for cultural events; } \\
\text { - } \text { Actors involved and Responsabilities; } \\
\text { - Suctware used; } \\
\end{array}$} \\
\hline & Concert and Tour Organizers & \\
\hline & Theatre producers and managers & \\
\hline & Congress Organizers & \\
\hline & $\begin{array}{l}\text { Booking Agency Managers, Concert } \\
\text { Organizers, Theatre producers and } \\
\text { managers, Congress Organizers }\end{array}$ & $\begin{array}{l}\text { - Comparison and Discussion of the results of } \\
\text { the previous Focus Groups in order to share } \\
\text { experience and identify best-practices }\end{array}$ \\
\hline
\end{tabular}

Fig. 1. Research method steps

For the analysis of the collected data, an interactive approach has been used to analyse and integrate the contributions of the different interviews and focus groups. During the interviews and focus groups, notes have been taken by two researchers per time. Notes have been useful to remember about the meaning of terms and create a structured set of information. After, each interviews and focus groups, the notes have been read and coded in order to highlighting the main concepts to be also further exploited in the later interviews and then, in focus groups, until the last one. The highlighted concepts 
describe the different activities and related characteristics for a live performance implementation with several levels of details. Concepts have been organized in categories representing the different lifecycle phases of an event. In the last focus group the followed approach, the emerged concepts and how they are integrated in categories were presented; feedbacks have been collected to re-arrange specific points and validate the overall picture. The result is, therefore, a chain of concepts explored and interrelated with the different actors involved and systematized in specific categories.

\section{$4 \quad$ Results}

The results section is organized in three parts: the description of event lifecycle phases and relevant process areas and the proposal of a data model for further developments.

\subsection{Event Lifecycle Phases}

Through the analysis of the information collected and the comparison and validation done in the last focus group, five phases of a lifecycle of an event emerges (fig. 2):

1. Ideation: it is the phase in which the need of a new event arises. In this phase, the type of event (e.g. concert, ballet), the place (e.g. a city, a Region or a square, a theatre), the typology of performance (e.g. rock music, hip hop music, drama, comedy), and the period (e.g. month, season) are defined.

2. Pre-production: all the critical decisions are taken, risks are evaluated and emerging problems are solved. Booking of artists, definition of date and place, evaluation of budget and available instrumentation, search of sponsors, the definition of the ticket costs are managed by a team of different professionals.

3. Production: it is full of activities to be executed to prepare the live performance. Negotiation with the artists and with the proposers are faced, the technical rider is received/generated. The location is evaluated and the different permissions are asked (e.g. use of public land authorization, serving food/alcohol to the public authorization, security and disability access prevision, copyright collecting agency permission). Service for audio and video are also defined. Timing of the event is also important to be analysed and established. Booking activities of the same event in different places are also carried out.

4. Execution and Distribution: it implies the activation of a tour and the live performance in the different established location. The technical rider is managed.

5. Closing and re-generation: when the tour is finished or the event is not more replicated (even in the case of once) or are not planned replication, the realized event is closed. Parts of the same event can be used to lead the conceptualization of new ones.

Monitoring of performance and activities is relevant in all the lifecycle phases, even if it is not currently completed done by all the actors and in all the phases. The use of indicators can be of time, costs and spectators reaction. It is also important to keep track of all the evaluation done in order to support decisions for future projects. 


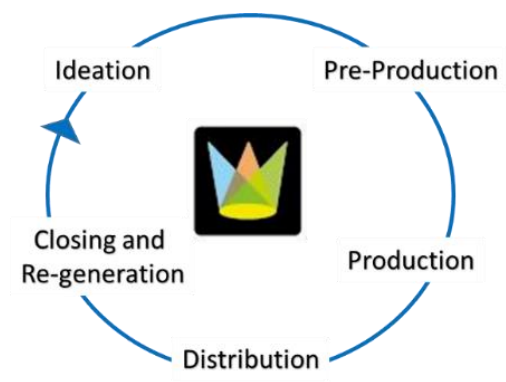

Fig. 2. Event Lifecycle Phases

\subsection{Relevant Process Area}

Managing the whole lifecycle of a Cultural and Creative Event is a very hard job and, often, it requires several people with different competencies to be completed successfully. As emerged from data collection, three Process Areas, that could be better managed with digital tools, have been identified: 1. Tour Management; 2. Configuration Management; and 3. Social Network Analysis.

In reference to the lifecycle phases, in the following figure there are reported the relations between processes areas and phases.

\begin{tabular}{|c|c|c|c|c|c|}
\hline \multirow{2}{*}{$\begin{array}{c}\text { PROCESS } \\
\text { AREAS }\end{array}$} & Ideation & $\begin{array}{c}\text { Pre- } \\
\text { Production }\end{array}$ & Production & Distribution & $\begin{array}{c}\text { Closing and } \\
\text { Re-Generation }\end{array}$ \\
\cline { 2 - 6 } & $\begin{array}{c}\text { Tour } \\
\text { Management }\end{array}$ & & & & \\
\hline $\begin{array}{c}\text { Configuration } \\
\text { Management }\end{array}$ & 0 & & & \\
\hline $\begin{array}{c}\text { Social Network } \\
\text { Analysis }\end{array}$ & & & & & \\
\hline
\end{tabular}

Fig. 3. Processes Areas and Phases

\subsubsection{Tour Management Process Area.}

The organization of a Tour is an activity that regards existing shows, probably tested with a pilot or a preview. It is possible to state that Ideation phase of the single event is not part of a Tour Management Area, although organizing a tour requires a certain amount of creativity, but more related to the advertising than to the contents.

An Event is unique but, usually, it is only one small part of a more complex set of shows called Tour. Thinking to the tour of a musician or to the one of a cirque, they both move from a location to another performing the same show each time. Tours can last a day or months and they can include events in one single or in more locations.

Although each event has its own characteristics, is important to manage some aspects of the whole Tour because it requires a great use of resources to move materials, manage accommodation, and comply with administrative obligations and so on.

The process to organize and manage a Tour is the Tour Management. In this process 
area, booking agents, artists, artist managers, tour managers and personal managers are mainly involved. It is becoming an increasingly important aspect in cultural and creative field, because always often the tour is one of the first sources of income.

\subsubsection{Configuration Management Process Area.}

A Configuration refers to how the structure of artists and instrumentations changes on the stage, in different performances. Configuration Management is related to the close connection that exists between a stage and the way to act a performance on that stage. It depends not on the performance itself but more on the physical space that the crew can use to make it. Different stages require different ways to make a performance and different configurations of the stage itself.

Moreover, the performance itself can change each time though the stage is the same. This is the case of Cirque du Soleil, the most famous cirque in the world. While a lot of Events are part of roadshows, a part of them is performed in the fixed locations (Montreal, Las Vegas, New York, and so on) the company has got. Each event is made up by several exhibitions, which differ for instrument used and number of people involved. Therefore, it is extremely important to plan the configuration of all of them and switch from one to another in the quickest possible way.

The Technical or "Contract" Riders are the documents that contain all the technical information useful for the preparation of the stage and can be useful in all the configuration management activities.

\subsubsection{Social Network Analysis Process Area.}

Social Network Analysis is a topic extremely important in the cultural and creative industries context, because usually a good marketing or promotion campaign on Social Networks can lead to an increase of products and tickets sold.

Social Networks are one of the most important sources of data and primary point of contact with the audience. Social Network analysis refers to the usage of data, taken from Social Networks, to evaluate a performance but also to create it. Thanks to the Social Networks, today is possible to understand users' preferences and receive, immediately, feedbacks about a performance done. These data could be used, for example, to improve the later performances and so they could affect ideation phase of a following event.

Furthermore, understand what are the most central members in a network is extremely important, because their role is essential to spread an information or influence the behavior of the other members of the network. Today, central members of a network are called influencer and their role is officially recognized on many social networks such as Twitter or Instagram.

Promoting an event on social networks, observing feedbacks both pre-event, during the event and post-event can release, therefore, important information for managing the event lifecycle. 


\subsection{A Data Model to Manage Cultural and Creative Product Lifecycle Information}

In the following section will be proposed a data model to support the Lifecycle Management of a Cultural and Creative Event. The Data Model proposed will be a valid starting point from which developing future software. It describes not only all the Data entities that a manager needs to take care while organizing an Event or a Tour, but it will be analyzed also the set of all the relationships existing among them.

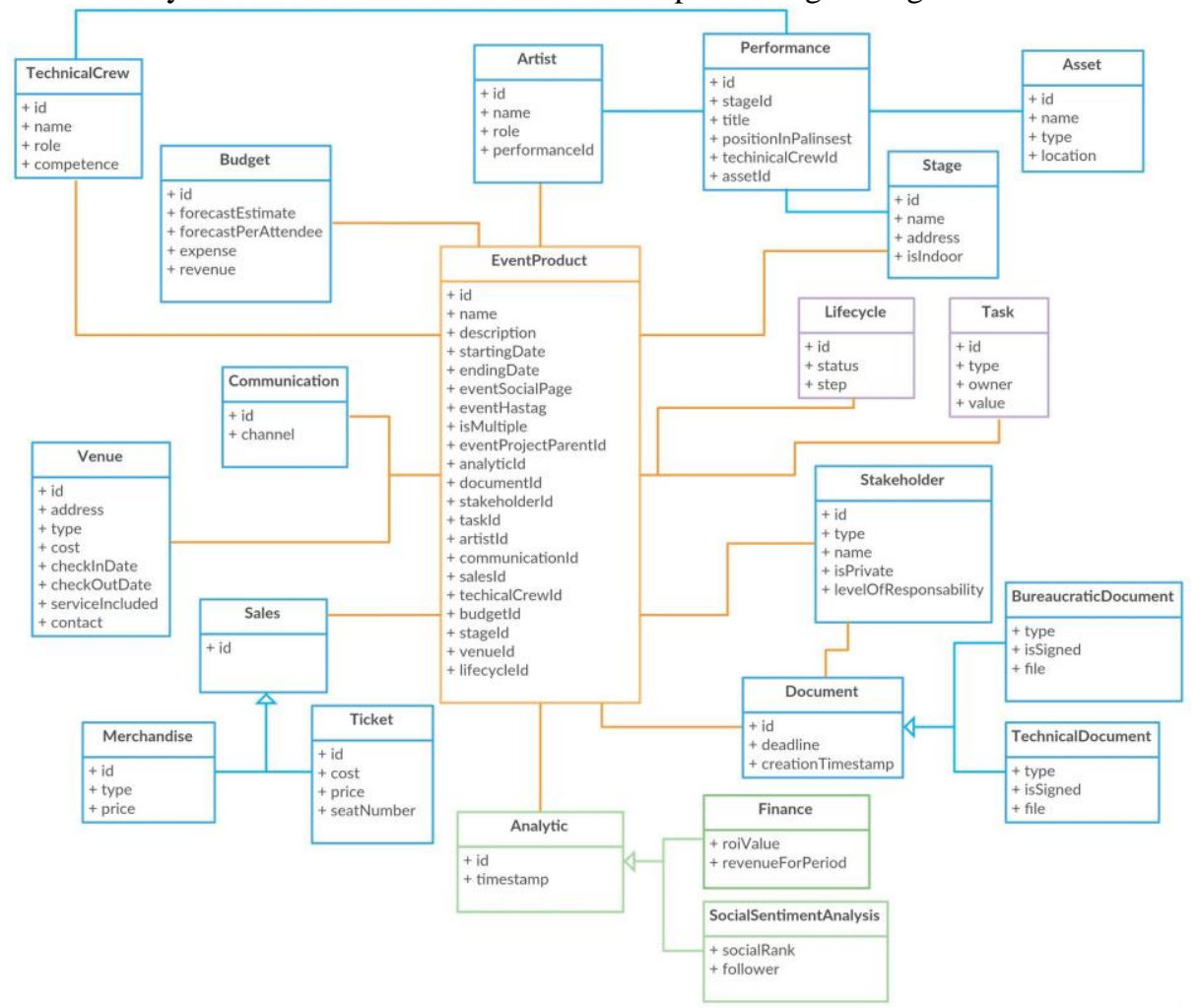

Fig. 4. Data Model Class Diagram

Six different groups of Classes have been identified. They represent the type of entities needed to manage the Cultural and Creative Event Lifecycle. People Group includes all the human resources involved in the Event both required to organize, manage and execute the Event, but also who will pay. Document Group includes all the information required to accomplish bureaucratic tasks and to keep track of technical requirements. Logistic Group includes all the aspects related to accommodation and transport, both for human and material resources. Also, the stage on which the performance will be executed is part of this cluster. Performance Group is the most important class because it represents the final product that prompts the end users to pay and the entity to which all the other ones are connected. Sales Group includes not only the tickets payed from final user but also all the income related to merchandise and advertising. Finally, the Social Network Group includes all the information and data extracted from web and 
social channels that can be used to evaluate the Event and to create new products.

The proposed data model (Fig. 4) is highly comprehensive and covers all the business cases analysed but can be further extended and specified in terms of entities and relationships, also depending on the needed implementation granularity.

The most important class, represents the Event object. It will be named as EventProduct and its attribute list includes (Fig. 5):

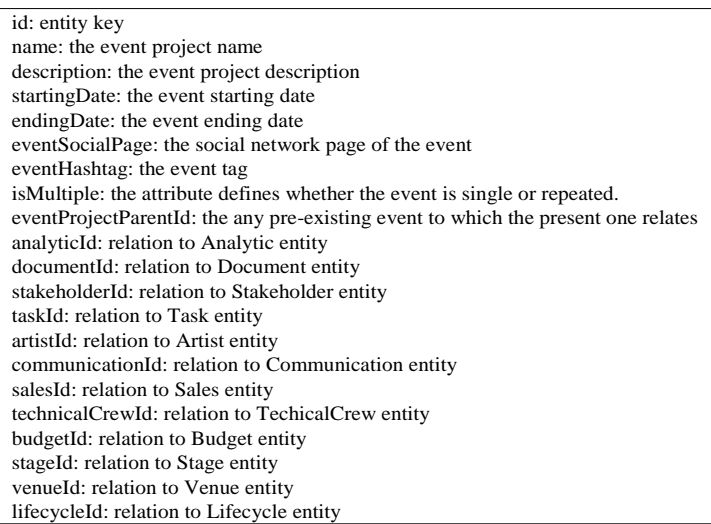

Fig. 5. EventProduct object entities

\section{Conclusion}

Compared to the studies in the literature concerning the application of PLM in unconventional sectors (food, fashion, luxury) where PLM applications in companies exist and scholars tried to assess how PLM is adopted, its limits and challenges, in the area of CCIs, the concept of PLM is not yet widespread. This study proposes a first approach focusing on performing arts among the different areas of the CCIs.

Event can be managed as a complex product with different parts, actors, responsabilities and risks involved and different tools to be used. Although the PLM is not considered, the issue of event lifecycle has already been addressed by few scholars ( [19], [23]), who focused on the application of NPD models and assuming a marketing or managerial perspective.

The needs of improve and innovate activities and lifecycle of events are emerged in different discussion with actors involved in the organization and execution of live performance.

The proposed lifecycle phases, processes areas and data model are the preliminary results of a structured study that will be carried out with a deep participation of the involved actors using a living lab methodology in order to reflect the real needs of the wide set of actors involved in an event.

As emerged by the paper results thus, a PLM thinking for events could support the CCIs for different processes. Benefits can be related to the information and asset management but also about the management of a whole event. Further studies will analyse 
in deep the benefits of the proposed approach in order to provide an appropriate evaluation based on the analysis of real cases.

Future research will deepen the lifecycle phases correlating for each phase also the information about actors involved, documents created/shared and software used. A methodology for proposing a more structured approach in event management will be defined and customized for specific targets of actors. A software solution will be developed in order to integrate and support the highlighted process areas and to establish a lifecycle management view.

\section{Bibliography}

1. EY, "Italia Creativa," 2016.

2. F. Colbert, Marketing Culture and the Arts, Montreal: Chair in Arts Management; 2nd edition, 2001.

3. Project Management Institute, A Guide to the Project Management Body of Knowledge (PMBOK® Guide), 5th ed., Project Management Institute, 2013, p. 589.

4. A. Saaksvuori and A. Immonen, Product Lifecycle Managemen, 2 ed., Berlin: SpringerVerlag Berlin Heidelberg, 2005. doi: 10.1007/b138258.

5. CIMdata, "Product Lifecycle Management - Empowering the Future of Business," 2002.

6. J. Stark, Product Lifecycle Management (Volume 3): The Executive Summary, Springer International Publishing, 2018. doi: 10.1007/978-3-319-72236-8.

7. A. Corallo, L. Maria Elena, L. Mariangela, S. Lettera, M. Marra e S. Verardi, «Defining Product Lifecycle Management: A Journey across Features, Definitions, and Concepts,» ISRN Industrial Engineering, vol. 2013, p. doi: https://doi.org/10.1155/2013/170812, 2013.

8. M. Grieves, Product Lifecycle Management: Driving the Next Generation of Lean Thinking, New york: McGraw-Hill , 2006.

9. J. Stark, Product Lifecycle Management. 21st Century Paradigm for Product Realisation, 2nd a cura di, London: Springer, 2011. 10.1007/978-0-85729-546-0.

10. D. Tang and X. Qian, "Product lifecycle management for automotive development focusing on supplier integration," Computers in Industry, vol. 59, no. 2-3, pp. 288-295. doi: 10.1016/j.compind.2007.07.002, 2008.

11. M. Alemanni, A. Grimaldi, S. Tornincasa and E. Vezzetti, "Key performance indicators for PLM benefits evaluation: The Alcatel Alenia Space case study," Computers in Industry, vol. 59, no. 8, pp. 833-841. doi:10.1016/j.compind.2008.06.003, October 2008.

12. M. Cantamessa, F. Montagna and P. Neirotti, "Understanding the organizational impact of PLM systems: evidence from an aerospace company," International Journal of Operations \& Production Management, vol. 32, no. 2, pp. 191-215. doi. https://doi.org/10.1108/01443571211208623, 2012.

13. A. Corallo, M. Lazoi, A. Margarito and D. Pinna, "Developing a PLM Framework: A Case Study Application in an Energy Company," in Product Lifecycle Management for Society. PLM 2013. IFIP Advances in Information and Communication Technology, 2013. doi: https://doi.org/10.1007/978-3-642-41501-2_16. 
14. S. Aram and C. Eastman, "Integration of PLM Solutions and BIM Systems for the AEC Industry," in Proceedings of the 30th ISARC International Symposium of Automation and Robotics in Construction and Mining, Montréal, Canada, 2013.

15. E. D'Avolio, R. Bandinelli and R. Rinaldi, "Improving new product development in the fashion industry through product lifecycle management: a descriptive analysis," International Journal of Fashion Design, Technology and Education, vol. 8, no. 2, pp. 108121. doi: https://doi.org/10.1080/17543266.2015.1005697, 2015.

16. E. Vezzetti, M. Alemanni and B. Morelli, "New product development (NPD) of 'family business' dealing in the luxury industry: evaluating maturity stage for implementing a PLM solution," International Journal of Fashion Design, Technology and Education, vol. 10, no. 2, pp. 219-229. doi: https://doi.org/10.1080/17543266.2016.1250286, 2017.

17. C. Pinna, M. Taisch e S. Terzi, «PLM in the food industry: an explorative empirical research in the Italian market,» in Product Lifecycle Management for Digital Transformation of Industries. PLM 2016. IFIP Advances in Information and Communication Technology, 2016. doi: https://doi.org/10.1007/978-3-319-54660-5_22.

18. C. Pinna, L. Plo, M. Rossi, V. Robin e S. Terzi, «Impact of PLM System in the New Food Development Process Performances: An Empirical Research,» in Product Lifecycle Management and the Industry of the Future. PLM 2017. IFIP Advances in Information and Communication Technology, 2017. doi: https://doi.org/10.1007/978-3-319-72905-3_47.

19. M. Crealey, «Applying New Product Development Models to the Performing Arts: Strategies for Managing Risk,» International Journal of Arts Management, vol. 5, n. 3, pp. 24-33, 2003.

20. R. Bennett and R. Kottasz, "Lead User Influence on New Product Development Decisions of UK Theatre Companies: An Empirical Study," International Journal of Arts Management, vol. 3, no. 2, pp. 28-39. url: http://www.jstor.org/stable/41064721, 2001.

21. A. Shone and B. Parry, Successful Event Management, A Practical Handbook, 3rd ed., Cengage Learning EMEA, 2010.

22. M. Lindgren and J. Packendorff, "Performing arts and the art of performing - On coconstruction of project work and professional identities in theatres," International Journal of Project Management, vol. 25, no. 4, pp. 354-364. doi: https://doi.org/10.1016/j.ijproman.2007.01.005, 2007.

23. K. Holmes e J. Ali-Knight, «The event and festival life cycle - developing a new model for a new context,» International Journal of Contemporary Hospitality Management, vol 29, n. 3, pp. 986-1004, 2017. doi: 10.1108/IJCHM-10-2015-0581.

24. D. Getz e S. J. Page, «Progress and prospects for event tourism research,» Tourism Management, vol. 52, pp. 593-631, $2016 . \quad$ doi: https://doi.org/10.1016/j.tourman.2015.03.007. 